\title{
IMPACT OF DOMESTIC VIOLENCE AND CLASH OF CULTURES ON SUBALTERN IDENTITY IN PURPLE HIBISCUS BY CHIMAMANDA NGOZI ADICHIE
}

\author{
Maryam Gholamian Abolfathi \\ Department of English, Ahvaz Branch, Islamic Azad University, \\ Ahvaz, Iran
}

Dr. Pushpa V K

Associate Professor, Department of English, Ahvaz Branch, Islamic Azad University, Ahvaz, Iran pushpaz@yahoo.co.in

\begin{abstract}
Many drastic issues regarding the spiritual, cultural, emotional, and intellectual wounds left by the colonizers are still ravaging in many African countries. The 'Subaltern East,' coupled with oppressive social conditions, makes the present state of women more precarious as it has been portrayed in the novel Purple Hibiscus by Chimamanda Ngozi Adichie. The paper investigates the gender-based violence, especially domestic violence in Purple Hibiscus It as traces the sensitive role of colonial systems, religion, Patriarchal values, politics and tradition in stimulating clashes as well as their propagation for female subjugation and exploitation; domestic violence and subaltern identity of the 'double exploited.' Post-colonial theories and Psycho-social theories are applied to evaluate the marginalization and abuse of women.
\end{abstract}

Keywords: Postcolonialism, Domestic violence, Subaltern identity, Exploitation, Adichie

\section{INTRODUCTION}

Subaltern, as a postcolonial term, denotes the exploited entities. In that case, the Subalterns in Chimamanda Ngozi Adichie's Post-colonial novel Purple Hibiscus are more subjugated than the name usually implies. The book critiques the associated violence on women, cultural clashes, Christian religious intervention, colonial forces, and gender discrimination due to patriarchal domination. Meanwhile, it also beckons many parallel critiques, the African Igbo culture through many characters whose belief systems manifest multifaceted possibilities for a safer space for women and the possibility of erecting a more protect world or at least a harmless secular age. Many Nigerian women writers like Chimamanda Ngozi Adichie, Lola Shoneyin, and Ayobami Adebayo, Akwaeke Emezi, Chinelo Okparanta, Sefi Atta, Yejide Kilanko, etc. introduce readers to many sagas of misfortunes, sufferings, and traumas of women. Although their characters are fictional representations, the problems depicted in their works are reflections of social oppression and the suffering multitudes from the pages of history. The paper critiques that apart from painting the pitiable plight of female subalterns, women writers, scholars, activists, and creative writers (Aidoo 1996) evoke human consciousness. Post-colonial, as well as contemporary Psycho-social theories, are applied to retrieve the oppression and struggle of women to gain their rights as depicted in the novel. Life for many women in Nigeria is the total of domestic violence, degradation, physical abuse, mental abuse, social restrictions, religious taboos, political suppression, patriarchal dominance, and physical assault. In this respect, women are genuinely subalterns. As a postcolonial novel, Chimamanda Ngozi Adichie's Purple Hibiscus critiques the colonial forces still working on subalterns. Purple Hibiscus depicts impeccable and rather contemporary issues affecting oppressed females in Nigerian society suffering from a myriad of problems. Recent studies show that there are two forms of gender violence in Nigeria; structural abuse and institutionalized violence (Amnesty International 2006). A report by the British Council entitled " Gender in Nigeria in 2012 " estimates that violence against women is a customary event and a socially supported affair. ( Nandi 2012; Zimmerman 1997) According to the UN, violence against women is the most pervasive violence of human rights (United Nations Secretary-General 2009); (Jekayinfe 2011; USAID 2008). World Bank data is shocking when it affirmed that 70 percent of women experience violence in one way or the other. (World Bank Data: 2014). Gender and violence are closely related (world Health Organization 2009.) Statistics and reports on Domestic violence and cultural inequalities announce that the practice of degrading another person to a distinctly unequal identity of "other" is the root cause of all material, social and political injustice. ( Stanley 2009). In eastern Nigeria, a clinic-based survey of 300 women reported $40 \%$ of them had experienced violence in the previous year ( Ilika 54). Such shocking statistics of human violation and female abuse flash in front when one reads Adichie's novel The Purple Hibiscus. 


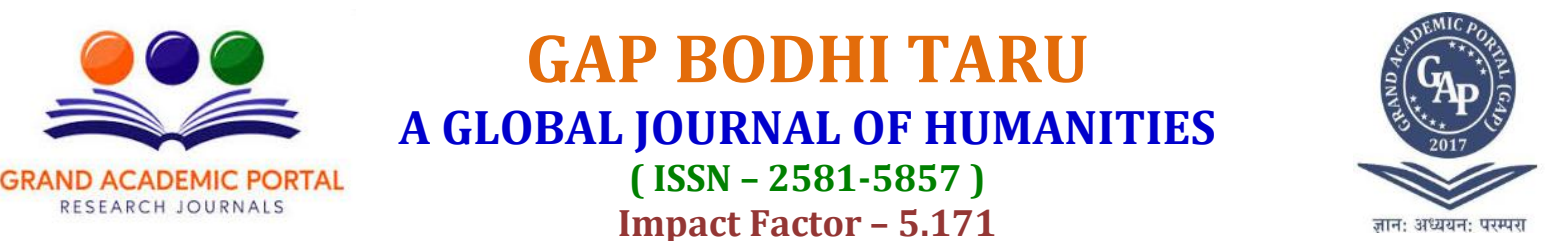

stubbornness superiority of ideology and expectations enforced upon inferiors or the ruled uphold supremacy. Father Benedict's insistence on conducting prayers only in Latin and not in the native Igbo language evolve out of the colonial world view of superiority that pervades in the day to day lives of Africans even centuries after the colonization.

It is appalling to watch the penetration of such world views into the daily life of Nigerians. The existing male supremacy and female subordination can trigger several social ailments. Among the social diseases, rape, physical assault, wife thrashing, female infanticide, and feminine circumcision top the list. Papa Eugene is a " colonial product." He continues the legacy of the civilized man. His intense devotion to Catholicism is his way of adopting the mindset of the colonizers- being superior and ill-treating even the close ones to establish his power, supremacy, and arrogance. In the name of culture and religion, he teaches lessons to family members based on his beliefs regarding the Christian religious ideology of sin and redemption. According to Charles $\mathrm{E}$ Bressler:

Postcolonial theory, on the other hand, moves beyond the bounds of traditional literary studies and investigates, social, political and economic concerns of the colonized and the colonizer. (Bressler 2012)

Therefore, an investigation based on 21st Century Post-colonial theory, aggressively criticizing the existing thoughts and beliefs regarding race and imperialism, will be equally useful to evaluate the ethnic clashes, cultural conflicts, marginalization of the subaltern, and abuse of women.

Eugene is a representative of Colonialism and the problems parades with it to the next generations. Susan Andrade, in her paper "Adichie's Genealogies; National and Feminine Novels' argues that while Purple Hibiscus represents politics of the family, at the same time, it narrates the tale of a nation. Therefore as Andrade (2011)says the novel, Purple Hibiscus plunges into many facets of contemporary life as Andrade says:

By illustrating cross-continental inspirations and interests in the book reveals Adichie's exploration of the modern Nigerian political crisis. (Andrade, p.91)

Many ideas of papa are rooted in the colonial system and patriarchal values. Papa thinks the right school has a high unsalable wall to keep the students protected and, of course, make school a place for discipline. Mama and Kambili are supposed to cover their hair and are not allowed to show their legs once they are in church. Whenever Papa saw her scarf slip away, he gets wild since he thinks it sinful for women to show one's hair in public. Papa, as an embodiment of patriarchal dominance, Jaja and Kambili live in frightened silence, whereas Ifemo's children are free, outspoken, and cheerful in the presence of their rational thinking mother.

Mama Beatrice always whispers. Kambili's mother is careful to keep everything hushed up and respectable, for she knows the outcome of the least pitfalls from her side. Ifeoma is proud and independent and chooses independence for wealth. Papa's physical assault and dominance of a typical patriarch has invariably ruined Kambili's little mind, and she feels everything except written in Papa's schedule as sins. Psychologically it has harmed the lives of Kambili and Jaja. Her silent withdrawal from friends and relatives affect her interpersonal relationships. To achieve the approval and appreciation of her patriarchal father, Kambili follows the 'scheduled' life papa wrote for the children on a piece of paper. Still, it invariably makes her gloomy and shut in a nutshell.

Walker, while discussing the racist folklore and preexisting literature, raised issues of dual colonization of black women and also their marginalized state in the male-dominant societies of Africa says that:

Black women are called, in the folklore, that so aptly identifies one"s status in society, "the mule of the world," because we have been handed the burdens that everyone else- everyone else- refused to carry. (Walker 237) By juxtaposing aunt Ifeoma's liberal, joyful attitude to children and papa's and Father Benedict's rigid, dogmatic thoughts of faith, Adichie poignantly portrays religion, or in that matter, any ideology can be repressive or beneficial according to the way we handle it. The difference in the doctrine of the two siblings from their attitudes towards the father. Adichie juxtaposes this perspective poignantly; papa's angry and sinister way of dealing with his father, Papa Nnukwe, as 'a heathen' is contrasted with Ifemo's intense love and affection for her father especially when he was sick and needed help. Eugene's colonial superiority and Christian mentality to decree his father from entering his mansion. Papa Nnukwu complains:

...look at me. My son owns that house that can fit in every man in

Abba, and yet many times, I have nothing to put on my plate. I should

not have let him follow those missionaries. ( Purple Hibiscus P.83)

How deep-rooted is papa's rigidity, and religious belief is reflected in Kambili's mental state when she mourns her grandfather. She is sad and mourning yet cannot stop thinking that she is sinning. She is also worried about her father's anger for defying him. Papa's sneer and disregard for his 'heathen' father are again juxtaposed with Ifeoma's children mourning for papa Nnukwe without any inhibitions.

Papa was a typical product of the missionary school and the colonizers. The missionary school priests punished papa for sinning. And now Papa wants to save Kambili from sinning in the typical catholic way as he had been trained once through brutal punishments. The catholic tradition of choosing an English name for Christian 


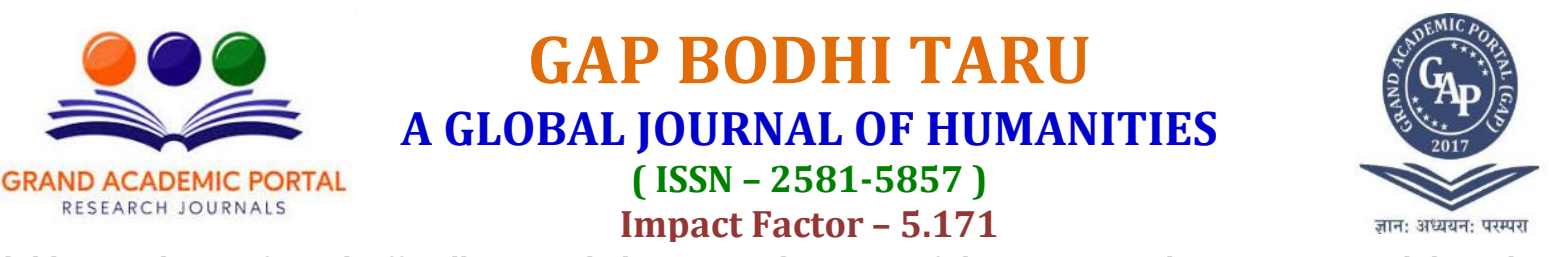

children to be confirmed officially as Catholics is another sign of the ongoing colonization. Kambili, in her dream, too connects the domestic tyranny with the political oppression in Nigeria.

What is more apparent in the plot of this postcolonial text is the confluence of these social systems in female subjugation, abuse, domestic violence, and suffering. Patriarchal cultures inherent in the Nigerian social traditions strengthened by the colonial male dominance have marginalized women as Subalterns. As a consequence, women are oppressed, both physically and mentally. Around the world minimum one out of 3 women is sexually abused or physically assaulted during her life, and most of it happens at the hands of a close male family member ( WHO 2004)) and 10-69 percent of women reported to be assaulted by an intimate partner (Krug.et al., 2002). According to UNFPA (2002), more than 60 percent of women have been abused all around the world. Women are always at the danger zone according to the previously published studies and reviews based on gender-based violence (Heise 1998; Hindin and Adair 2012; Jewkes et al. 2002; Karamagi et al. 2006).

\section{DOMESTIC VIOLENCE}

Colonizers left Nigeria, and slavery is indeed abolished. Still, the prickly halo of a system they left behind along with patriarchal values and the native cum Christian religious values left no room for women in terms of their growth, development, and self-awareness. As colonialism was harmful to all genders, so also the existing replaced systems (patriarchal traditions) watered by the colonial ideologies of superiority and religious dogmas. It is just a new form of patriarchy becoming active in the oppression of women. Nevertheless, the ugly versions of misuse of power, supremacy, and violence still pervade in and out of the microcosm of society- the family.

Adichie envisages the ongoing parade of disorder, pain, and how it demolishes the identities of many human beings through the symbolic representation of 'figurines' in the novel. When Jaja refused to participate in the communion, Papa Eugene throws the prayer book at him. The violent punishments are a sign of his love, a powerful man's way to teach his wife and children the right direction. Breaking the figurines is part of that bursting violence that escalates in the domestic sphere.

Kambili remembers how her mother meticulously polished the figurines, especially after she was beaten up by papa Eugene. Papa takes off his belt and beats them all whenever he thinks that they are deviating from his supremacy.

Papa was like a Fulani nomad-as he swung his belt at Mama, Jaja, and me muttering that the devil will not win. We did not move two steps away from the leather belt that swished through the air.

( Purple Hibiscus P.102) The pity is that papa's sense of sin and punishments are deeply ingrained in his subconscious mind that women and children deserve these punishments to proceed in the right path. Papa throws hot boiling water on Kambili's feet to save her from sins. Jaja, too, had become the target of papa Eugene's abuse. Eugene smashed Jaja's little finger as a punishment for not being first in the Holy Communion class. When Kambili and Jaja are at Nnukwe's house, mama comes to announce that papa had broken a table on her belly. The reason for her continuous miss carriages is nothing but papa's violent physical abuse and assault.

Patriarchal systems and traditional native values applied social stigmas to oppress women. Domestic violence and physical abuse are a potent means to subjugate and dehumanize female identities. The cycle of oppression, violence, and tyranny was at the peak politically, and its representation in the domestic level occurs in the form of personal tyranny of papa when mama denied papa's request to visit Father Benedict. Eugene thrashed her behind the closed doors of their bedroom until she became like a bleeding gunny bag.

We stood at the landing and watched papa descend. Mama was slung over his shoulders, like the jute sacks of rice, his factory workers brought in bulk at the same border....."There's blood on the floor.' Jaja said. "I'll get the brush from the bathroom." We cleaned the the trickle of blood, which trailed away as if someone had carried a leaking jar of watercolor all the way downstairs.

( Purple Hibiscus P. 33)

On another occasion, the father slaps Kambili's face. Kambili's and Jaja's arrogance to bring papa Nnukwu's painting drive papa into a manic rage. He yelled and went on kicking her with his metal buckled shoes as her 


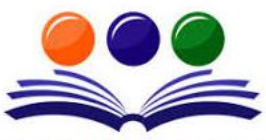

GRAND ACADEMIC PORTAL RESEARCH JOURNALS
A GLOBAL JOURNAL OF HUMANITIES

\author{
( ISSN - 2581-5857) \\ Impact Factor - $\mathbf{5 . 1 7 1}$
}

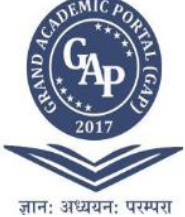

delicate body lay curled up on the floor bleeding. He has nearly beaten her to death as she lay on the floor on top of the torn pieces of her grandfather's painting with a broken rib and internal bleeding.

The figurines somewhat act as the euphemism for domestic violence and the false front of papa Eugene, the patriarch. He is a wealthy, well respected, and ever praised by Father Benedict in the church as an example of a pious, ideal man. In contrast, the broken pieces of figurines are the ironic representation of the patriarch camouflaged as papa Eugene. No wonder, Adichie sketches the real picture of an influential, reasonably wealthy man in the shoes of a typical evil traditional patriarch. Rationally, one can imagine the innumerable women and children suffering at the hands of illiterate, superstitious men from the not well to do strata of society. As reflected in the works of some women, novelists of African origin, the empirical researches conducted in Nigeria on physical abuse are proof of domestic violence. The findings of various studies conducted in Africa report the extreme physical violence and abuse of women. (Askew 2006; WHO 2004.) And the rates reported may be higher in reality since the field studies on domestic violence, especially in Nigeria, as shown in the physical violence study and survey by Anderson et al. (2007), Gracia Morenc et al. (2006) many cases remain unreported or hidden from the public.

\section{DOMESTIC VIOLENCE AND ITS PSYCHOLOGICAL IMPACT}

Psychologically speaking, domestic violence has its repercussions in the psyches of women who undergo physical assault. The force of such atrocities committed right in front of the young children at their own homes by their parents affects their young minds. Kambili is locked in her childhood. Kambili suffers psychologically more than physically from the constant physical assault of her father. She is also mentally devastated by the way papa beats her mother, and she secretly wishes her father's death. She detests her mother's meek submissiveness, and at times, wonders why her mother is not supporting her children from their evil father. Unable to grow up in a peaceful atmosphere, Kimbili follows a world full of violence silently and practice an enforced silence. That might be the reason why Amaka, her cousin, thinks them 'abnormal,' and she asks her mother about Kambili and Jaja whether 'something is not right with them.'

Papa's violent and governing nature of a typical patriarch has mentally ruined Kambili, and she feels everything except what is not written in Papa's schedule are sins. Psychologically it has destroyed her growth as an individual. Her silence naturally impacts barred her from interacting with others, from having fun and relishing the joy of relationship. Kambili always tried to get approval and appreciation from her patriarchal father but ended up gloomy and isolated from lack of contacts.

\section{SUBALTERN IDENTITY- YIELDING TO DOCILITY AND PATRIARCHHAL VALUES}

The Purple Hibiscus portrays specific indispensable reasons for domestic abuse of women through the fictional world of Adichie. Accepting one's fate or docility can be one of the reasons for the underlying violence. Mama submits to domestic oppression, so also Kambili and Jaja. One wonders whether the God-like father figure in young Kambili's mind is the typical image of a man in the subconscious mind of every child, which gradually turns into a willful submission to patriarchal values and yielding to docility. Mama and Kambili think it a plus point. The gossip in the family that mama Beatrice is not getting another child and their suggestion to take a new wife for bearing more children etc. are part of mental abuse and also part of domestic violence practiced all over the world.

Not only are physical assaults committed on their mother, but there are also mental tyrannies on the family members by controlling every movement of their lives. The written daily schedule pinned on the wall, and the children carry everywhere specifying the time for doing everything even 'family time' specified on it is an example of the lack of freedom. Censorship is a means of tyranny that can harm human development in any facets of life. Ade coke is unaware of the abuse going on in his boss' family. Yet, he notices the discrepancy between papa's personal life and ideology, the way he treats his children, and expectation of complete submission of his family members. Kambili clings to her guilt at breaking papa's rules, whereas Jaja moves past such guilty feelings later. Kambili always longed for her father's approval for her happiness. She studies hard to stand first in class, and please papa. Such thoughts are reflections of the bondage; One finds it hard to break off. Mama feels the same. She tolerates torture, abuse, and violence daily because she leads a life of dependence. Mama's status raises many social and ethical questions. Why should the majority of women suffer in many Eastern or African countries? Why should women, especially African women, be more at risk of violence? An article on “ The Guardian' on Monday 26 $6^{\text {th }}$ November 2018 points out in the section "Why are African women more at risk of violence? Nigeria tells a patriarchal tale" by Sede Alonge that women still live in a country where society often justifies female subjugation. Many crimes are committed on a routine basis, or many waves of abuse appear to be regular events. UN report on Women in Africa and their risk of violence shows that $23 \%$ of women have been victims of physical or sexual assault by their husbands. In contrast, much domestic violence goes unreported, and many are committed to concealed premises. In a country of 194 million people, $23 \%$ 


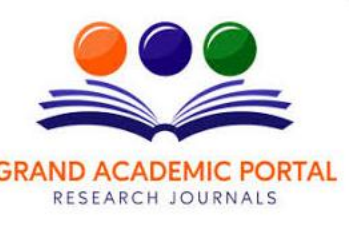

\title{
GAP BODHI TARU A GLOBAL JOURNAL OF HUMANITIES
}

\author{
( ISSN - 2581-5857) \\ Impact Factor - 5.171
}

l sociology, 191-204.DOI:10.4135/9781848608238.n14(2000).

Gracia-Moreno C, Jasen H, Ellsberg M, Heise L, Watts C (2006).Prevalence of intimate partner violence: findings from the W.H.O multi-country study of women's health and domestic violence. Lancet. 368: 1260-1269.

Heise L. Violence against women: an integrated ecological framework Violence against women, 4: 1998. P. 262-290.

Hindin MJ, Adair LS (2002). Who is at Risk? Factors Associated with Intimate Partner

Violence in the Philippines. Soc. Sci. Med., 55: 1385- 1399.

Ilika, Amobi L., et al. "Intimate Partner Violence among Women of Childbearing Age

in Aid Primary Health Care Centre in Nigeria." African Journal of Reproductive Health / La Revue Africaine De La Santé Reproductive, vol. 6, no. 3, 2002, pp. 53-8 JSTOR www.jstor.org/stable/3583257.

Jewkes R, Sen P, García-Moreno C (2002). "Sexual violence.” In: E.G., Krug, et al. (Eds.) World Health Report on Violence and Health. World WHO; Geneva. Pp 148181.

Karamagi CA, Tumwine JK, Tylleskar T, Heggenhougen K (2006). Intimate partner violence against women in Eastern Uganda: implications for HIV prevention. BMC Public Health, 6: 284.

Krug E, Dahlberg L, Mercy J (2002). World Report on violence and health. WHO Geneva, Switzerland.

Kashani, Javad H, and Wesley D. Allan. The Impact of Family Violence on Children and Adolescents. Thousand Oaks, CA: Sage Publications, 1998. Print.

Lindsay, Lisa A. Men and Masculinities in Modern Africa (Social History of Africa Series). Ed. Miescher, Stephen F. Portsmouth: Heineman June 20, 2003

McClary-Jeffryes, Theresa M., "Modalities of Injustice in the Subaltern Discourse" Masters Theses \& Specialist Projects.Paper 1621 (2016).

Nasir K, Hyder AA. Violence among pregnant women in developing countries: Review of the literature. Eur. J. Public Health, 13(2): 2003. P. 105-7

NDHS. Nigeria Demographic and Health Survey 2003

Rohini Harsh. Representation of Chauvinistic Model of Religion and

Individualistic Nature of Faith in Chimamanda Ngozi Adichie's Purple Hibiscus,

Vol.3; April 2017. ISSN: 2454.2423

Sahoo, A. Subaltern Studies: A new trend in writing history. Odisha Review, (November), 81-86. (2014)

Spivak, G. Can the subaltern speak?. In C. Nelson \& L. Grossberg (Eds.), Marxism and the Interpretation of culture (pp. 271-303). London: McMillan. (1988).

The Universal Declaration of Human Rights | United Nations. (n.d.). Retrieved Feb.01, 2016 from http://www.un.org/en/universal-declaration-human-rights/

The World Bank, October 01). Governments should focus on shared prosperity to address inequality - World Bank group president [ Press Release ] Retrieved from http://www.worldbank.org/en/ news/press-release/2015/10/01/governments-. (2015).

UNFPA; World Report on Violence and Health. Geneva.2002 United Nations General Assembly; Declaration on the elimination of violence against women. Proceedings Of the 85th plenary meeting, Geneva.1993.

Urama, Evelyn Nwachukwu Gender, Leadership, and the Igbo Woman: A study of Some Selected Works of Akachi Adimora-Ezeigbo and Chimanda Ngozi Adichie Ars

Artium: An International Peer Reviewed-cum-Refereed Research Journal of English Studies and culture ISSN (Online): 2395-2423 ISSN (Print): 2319-7889 Vol. 7,

January Pp. 56-66 ( 2019)

WHO; Summary Report World Health Organisation. WHO multi-country study on women's Health and Domestic violence against women: summary report of initial results on prevalence, health outcomes, and women's responses, Geneva, Switzerland, WHO 2005

World Health Organization; Preventing violence: a guide to implementing the recommendations of the World report on violence and health.2004 